\title{
Relationships between Structures and Liquid Crystalline and Optical Properties in Combined-type Copolyisophthalates Having Nitro- and Methoxyazobenzene Units and Aliphatic Spacers in the Side Chain
}

\author{
Moriyuki $\mathrm{SATO}^{\dagger}$ and Miyuki MizOI \\ Department of Material Science, Faculty of Science and Engineering, Shimane University, \\ 1060 Nishikawatsu, Matsue 690-8504, Japan
}

(Received February 18, 2004; Accepted April 28, 2004; Published August 15, 2004)

\begin{abstract}
Combined-type thermotropic liquid crystalline (LC) homo- and copolyisophthalates having nitroand methoxyazobenzene units and three aliphatic spacers (hexamethylene, octamethylene and decamethylene) in the side chain and biphenyl unit in the main chain were prepared by melt polycondensation and relationships between polymer structures and LC and optical properties were discussed. Differential scanning calorimetry (DSC) measurements, optical texture observations using polarizing microscopy and powder X-Ray analyses indicated that the homopolyisophtalates with the nitroazobenzene unit form highly ordered smectic $\mathrm{E}$ phase and the other homo- and copolymers show less ordered smectic B or smectic $\mathrm{C}$ phase. The temperature ranges of smectic LC phases in the polymers decreased with increasing the methoxyazobenzene content. In these polymers, specific interaction such as electron donor-acceptor interaction between the nitro- and the methoxyazobenzene units plays no role in the formation and the stabilization of smectic LC phases. All the polymers displayed UV-vis absorption peak maxima on the basis of the azobenzenes or the biphenyl in solutions and in films, but no fluorescent properties were found, probably due to intraand intermolecular quenching. [DOI 10.1295/polymj.36.607]

KEY WORDS Combined-type Polyisophthalate / Melt Polycondensation / Liquid Crystalline Property / Optical Property / Azobenzene / Biphenyl / Differential Scanning Calorimetry / Smectic Phase /
\end{abstract}

It is well known that there are three types of polymers in thermotropic liquid crystalline (LC) polymers: (1) main-chain polymers, (2) side-chain polymers and (3) combined-type polymers. ${ }^{1}$ The combined-type polymers, which have calamitic mesogens such as biphenyl, diphenyls and azobenzenes both in the side and the main chains, tend to have broader LC temperature ranges of mesophases than the parent main-chain and side-chain polymers and to show nematic phase together with smectic phases owing to the synergy effect of mesogens in the side and the main chains. ${ }^{2} \mathrm{Re}-$ searches on the combined-type LC polymers are still not adequate, ${ }^{3}$ although a number of literatures on chemical and physical properties of main-chain and side-chain LC polymers have been reported. ${ }^{4,5}$

On the other hand, side-chain azobenzene-containing polymers have attracted much attention because of potentials as polymers for photonics applications $^{7-16}$ in addition to LC properties. ${ }^{4,17}$ The azobenzene derivatives have been known for displaying no photoluminescence (PL), but it has been found that the azobenzene derivatives ${ }^{18}$ and poly $(p$-phenylenevinylene)s (PPV) ${ }^{19}$ having side-chain methoxyazobenzene unit emit PL light, having very low quantum yields. ${ }^{18}$ Our previous paper ${ }^{20}$ has described that novel combined-type semi-rigid homopolyisophthalates having biphenyl or 2,5-diphenyl-1,3,4-thiadiazole (DTD) unit in the main chains and azobenzene moieties in the side chains are synthesized by melt polycondensation and that most of them form stable smectic LC (B, C and E) phases without showing nematic phase in spite of the presence of different mesogens both in the side and the main chains, although unfortunately the polymers show no PL emission. Combinedtype polymalonates having the main-chain biphenyl and the side-chain methoxyazobenzene units have been reported to form higher ordered smectic phases in addition to smectic $\mathrm{A}$ and $\mathrm{C}$ phases. ${ }^{2,21}$ Kodaira et al. disclosed that copolymalonates with the sidechain nitroazobenzene and methoxybiphenyl units have wider temperature ranges of nematic phase than the homopolymalonates, where electron donor-acceptor interaction between the mesogens with electron-donating and electron-withdrawing groups acts an important role. ${ }^{22}$ In addition, copolymers containing monomer units with specific interaction such the electron donor-acceptor interaction have been found to form smectic mesophases. ${ }^{23,24}$

The purpose of this work is to examine the LC and optical properties of combined-type homo- and copolyisophthalates $\mathbf{5 a}-\mathbf{g},(m=6), \mathbf{6 a}-\mathbf{g}(m=8)$ and $7 \mathbf{a}-\mathbf{g}(m=10)$ constituted of aliphatic chains with

${ }^{\dagger}$ To whom correspondence should be addressed (E-mail: msato@ @iko.shimane-u.ac.jp). 
<smiles>CCOC(=O)c1cc(O)cc(C(=O)OCC)c1</smiles><smiles></smiles>

1
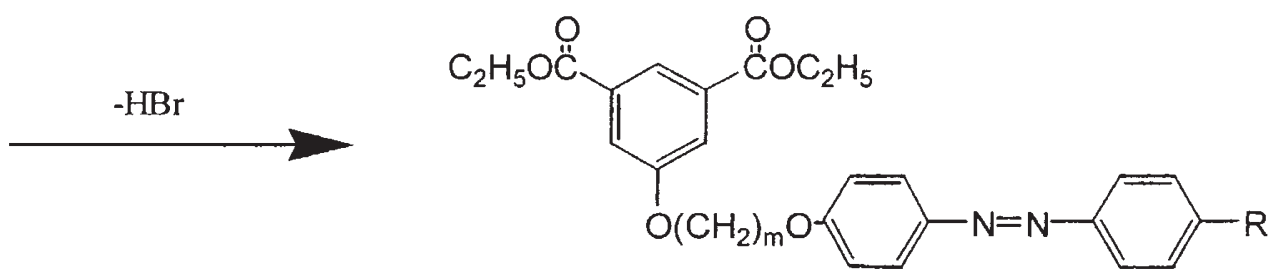

3

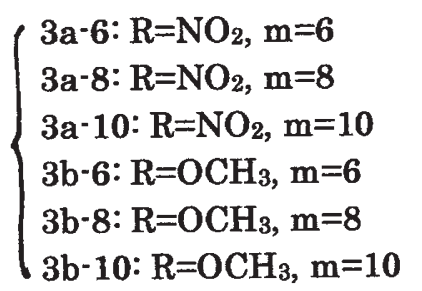

Scheme 1. Synthesis of monomers 3.

different lengths and the above-mentioned main-chain biphenyl unit and two side-chain azobenzene (nitro and methoxy) moieties, which were prepared using six diethyl isophthalates 3 of azobenzenes as monomers, in order to disclose relationships between polymer structures and LC and optical properties in combined-type polyesters having different mesogens both in the side and the main chains in more detail. It is expected that these combined-type homo- and copolyisophthalates $\mathbf{5 b}-\mathbf{f}, \mathbf{6 a}-\mathbf{g}$ and $\mathbf{7 b}-\mathbf{f}$ exhibit interesting properties and wider temperature ranges of LC (smectic) phases compared with our above-described homopolyisophthalates $5 \mathbf{a}, 5 \mathrm{~g}, \mathbf{7 a}$ and $\mathbf{7 g}$ with the mainchain biphenyl or DTD unit and the side-chain azobenzenes, ${ }^{20}$ because they bear both the electron-withdrawing nitroazobenzene and the electron-donating methoxyazobenzene units spaced by aliphatic chains (Schemes 1 and 2).

\section{EXPERIMENTAL}

\section{Characterization}

${ }^{1}$ H NMR spectra were obtained on a LEOL LMN EX270 spectrometer in deuteriated chloroform $\left(\mathrm{CDCl}_{3}\right)$. FT IR spectra were recorded with a Jasco FT/IR 5300 spectrometer by $\mathrm{KBr}$ disk method. Ultraviolet-visible (UV-vis) and PL spectra were measured on a Jasco V-560 UV/VIS spectrometer or Shimadzu UV-vis 3100 spectrophotometer and on a Hitachi 850 fluorescence spectrometer, respectively.
Differential scanning calorimetry (DSC) measurements were performed on a Shimadzu DSC 60 calorimeter at a heating and a cooling rate of $10^{\circ} \mathrm{C} / \mathrm{min}$ in nitrogen. Optical textures were observed with a $\mathrm{Ni}$ kon polarizing microscope equipped with a hot plate (magnification: $\times 200$ ). X-Ray analyses of polymers quenched from the LC states were carried out using a Rigaku Denki RINT 2200 generator with $\mathrm{CuK} \alpha$ irradiation. Number average molecular weights $\left(M_{\mathrm{n}}\right)$ and molecular-weight distributions were estimated by size exclusion chromatography (SEC) with a Jasco 830-RI refractometer and a column combination $(\mathrm{K}-803 / \mathrm{K}-$ 804) (Shodex), using polystyrene standards in chloroform as an eluent.

\section{Materials}

Acetone was purified by distillation after dryness. Commercially available potassium carbonate and zinc acetate were used as received. Diethyl 5-hydroxyisophthalate ${ }^{7} \mathbf{1}, 11,11^{\prime}$-(4,4'-biphenylenedioxy)diundecanol $^{25}$ 4, 1-nitro-4-[4-(6-bromohexyloxy)phenylazo]benzene $^{26}$ 2a-6, 1-nitro-4-[4-(8-bromooctyloxy)phenylazo]benzene ${ }^{27}$ 2a-8, 1-nitro-4-[4-(10-bromodecyloxy)phenylazo]benzene ${ }^{26}$ 2a-10, 1-methoxy-4-[4-(6-bromohexyloxy)phenylazo]benzene ${ }^{27}$ 2b-6, 1-methoxy-4-[4-(8bromooctyloxy)phenylazo]benzene ${ }^{26} \mathbf{2 b - 8}$ and 1-methoxy-4-[4-(10-bromodecyloxy)phenylazo]benzene ${ }^{28}$ 2b-10 were prepared according to the literatures. Diethyl 5-\{6-[4-(4-nitrophenylazo)phenoxy]hexyloxy $\}$ isophthalate 3a-6, Diethyl 5-\{10-[4-(4-nitrophenylazo)- 

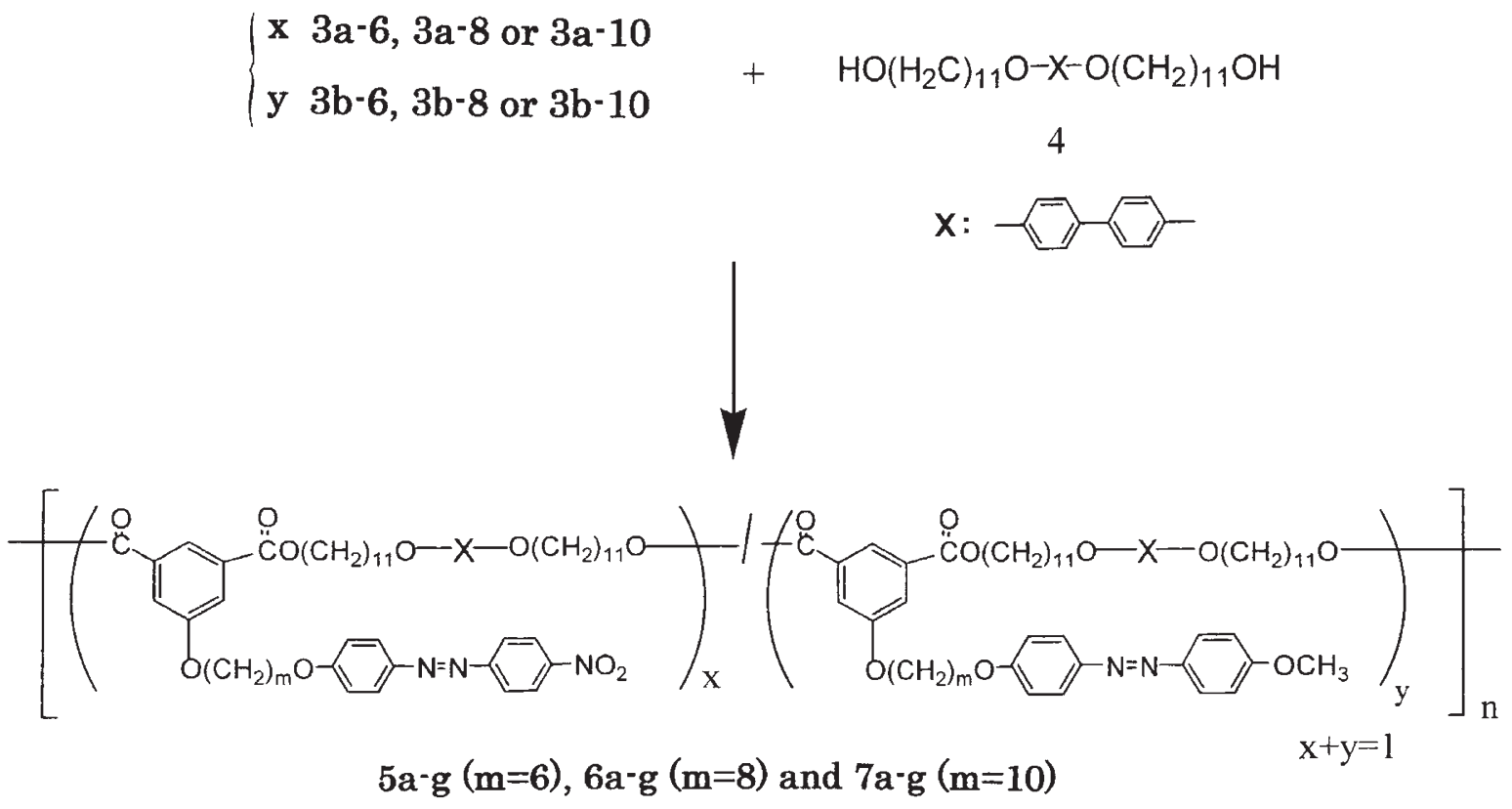

Scheme 2. Synthesis of polymers $5 \mathbf{a}-\mathbf{g}, \mathbf{6} \mathbf{a}-\mathbf{g}$ and $\mathbf{7 a}-\mathbf{g}$.

phenoxy]decyloxy $\}$ isophthalate 3a-10, Diethyl 5-\{6[4-(4-methoxyphenylazo)phenoxy]hexyloxy \}isophthalate 3b-6 and Diethyl 5-\{10-[4-(4-methoxyphenylazo)phenoxy]decyloxy\}isophthalate $\mathbf{3 b}-\mathbf{1 0}$ were synthesized by our previously-reported procedures. ${ }^{20}$

\section{Monomer Syntheses}

Diethyl 5-\{8-[4-(4-Nitrophenylazo)phenoxy]octyloxy isophthalate $(\mathbf{3 a - 8})$. Isophthalate compound $\mathbf{1}$ $(5 \mathrm{mmol}, 1.19 \mathrm{~g})$ and bromooctyloxyazobenzene derivative $2 \mathbf{a - 8}(5 \mathrm{mmol}, 2.17 \mathrm{~g})$ were refluxed in acetone $(20 \mathrm{~mL})$ in the presence of potassium carbonate $(7.5 \mathrm{mmol}, 1.04 \mathrm{~g})$ under nitrogen. After reaction for one day, the mixture was cooled and poured into water to precipitate the azobenzene compound $\mathbf{3 a - 8}$. The precipitate was filtered off and washed thoroughly with water. Then the product $\mathbf{3 a - 8}$ was recrystallized from acetone three times and dried at $60^{\circ} \mathrm{C}$ for $12 \mathrm{~h}$ under vacuum. Yield: $72 \%$. m.p.: $113-115^{\circ} \mathrm{C}$.

$\left(\mathrm{C}_{32} \mathrm{H}_{37} \mathrm{~N}_{3} \mathrm{O}_{8}\right)$ (591.7) Calcd. C 64.96, H 6.30, N 7.10\%; Found C 64.93, H 6.24, N 6.98\%.

${ }^{1} \mathrm{H} \mathrm{NMR}\left(\mathrm{CDCl}_{3}\right): \delta 8.35(2 \mathrm{H}, \mathrm{d}), 8.26(1 \mathrm{H}, \mathrm{s}), 7.97$ $(4 \mathrm{H}, \mathrm{q}), 7.74(2 \mathrm{H}, \mathrm{s}), 7.04(2 \mathrm{H}, \mathrm{d}), 4.40(4 \mathrm{H}, \mathrm{q}), 4.06$ $(4 \mathrm{H}, \mathrm{m}), 1.84(4 \mathrm{H}, \mathrm{m}), 1.57(6 \mathrm{H}, \mathrm{m}), 1.41 \mathrm{ppm}(8 \mathrm{H}$, $\mathrm{m})$.

FT IR (KBr): 2945, 2875 (CH stretching), 1718, 1715 (ester $\mathrm{C}=\mathrm{O}), 1600,1578,1498(\mathrm{~N}=\mathrm{N}$ or aromatic $\mathrm{C}=\mathrm{C}), 1520,1340\left(\mathrm{NO}_{2}\right), 1236 \mathrm{~cm}^{-1}(\mathrm{C}-\mathrm{O}-\mathrm{C})$.

Diethyl 5-\{8-[4-(4-Methoxyphenylazo)phenoxy]octyloxy\}isophthalate $(\mathbf{3 b - 8})$. The compound $\mathbf{3 b - 8}$ was prepared from bromooctyloxyazobenzene derivative $\mathbf{2 b - 8}(5 \mathrm{mmol}, 2.10 \mathrm{~g})$ and isophthalate $\mathbf{1}(5 \mathrm{mmol}$, $1.19 \mathrm{~g}$ ) in acetone $(20 \mathrm{~mL})$ in nitrogen by the same method to that for the nitroazobenzene derivative 3a-8 and recrystallized from acetone three times. Yield: $79 \%$. m.p.: $114-115^{\circ} \mathrm{C}$.

$\left(\mathrm{C}_{33} \mathrm{H}_{40} \mathrm{~N}_{2} \mathrm{O}_{7}\right)$ (576.7) Calcd. C 68.78, H 6.99, N 4.86\%; Found C 68.82, H 7.00, N 4.85\%.

${ }^{1} \mathrm{H}$ NMR $\left(\mathrm{CDCl}_{3}\right): \delta 8.26(1 \mathrm{H}, \mathrm{s}), 7.87(4 \mathrm{H}, \mathrm{q}), 7.74$ $(2 \mathrm{H}, \mathrm{s}), 7.01(4 \mathrm{H}, \mathrm{m}), 4.40(4 \mathrm{H}, \mathrm{q}), 4.04(4 \mathrm{H}, \mathrm{m}), 3.89$ $(3 \mathrm{H}, \mathrm{s}), 1.83(4 \mathrm{H}, \mathrm{t}), 1.57(6 \mathrm{H}, \mathrm{t}), 1.41 \mathrm{ppm}(8 \mathrm{H}, \mathrm{m})$.

FT IR (KBr): 2940, 2855 (CH stretching), 1726 (ester $\mathrm{C}=\mathrm{O}), 1603,1580(\mathrm{~N}=\mathrm{N}$ or aromatic $\mathrm{C}=\mathrm{C})$, $1501,1233 \mathrm{~cm}^{-1}(\mathrm{C}-\mathrm{O}-\mathrm{C})$.

\section{Synthesis of Polymers $5 \mathbf{a}-\mathbf{g}, \mathbf{6} \boldsymbol{a}-\mathbf{g}$ and $7 \boldsymbol{a}-\mathbf{g}$}

Typical synthetic procedure for copolyester $\mathbf{5 e}$ was described. A mixture of isophthalate 3a-6 $(0.2 \mathrm{mmol}$, $0.113 \mathrm{~g})$ and $\mathbf{3 b}-\mathbf{6}(0.3 \mathrm{mmol}, 0.110 \mathrm{~g})$ taken in a definite feed mole ratio and monomer $4(0.5 \mathrm{mmol}$, $0.263 \mathrm{~g}$ ) was stirred at $180-190^{\circ} \mathrm{C}$ for $2 \mathrm{~h}$ in the presence of zinc acetate $(5 \mathrm{mg})$ as a catalyst in nitrogen atmosphere. The reaction temperature was raised at $200-210^{\circ} \mathrm{C}$ during $30 \mathrm{~min}$ and then the reaction mixture was reacted at $200-210^{\circ} \mathrm{C}$ for $30 \mathrm{~min}$ at 16 Torr. Finally the system was reacted at the same temperature for $1.5 \mathrm{~h}$ below 1 Torr. After the completion of polymerization, the resulting solid was dissolved in chloroform and the solution was poured into methanol to reprecipitate the polymer $5 \mathrm{e}$. The precipitated product was filtered off, washed thoroughly with water and refluxing methanol three times and dried at $60^{\circ} \mathrm{C}$ for $1 \mathrm{~d}$ at a reduced pressure. Yield: $83 \%$. 
Table I. Synthetic results for polyesters $\mathbf{5 a}-\mathbf{g}$

\begin{tabular}{|c|c|c|c|c|c|c|c|c|c|}
\hline \multirow{2}{*}{ Polym. } & \multirow{2}{*}{$x: y$} & \multirow{2}{*}{$\begin{array}{l}\text { Yield } \\
(\%)\end{array}$} & \multirow{2}{*}{$M_{\mathrm{n}}{ }^{\mathrm{a}}$} & \multirow{2}{*}{$M_{\mathrm{w}} / M_{\mathrm{n}}^{\mathrm{a}}$} & \multirow{2}{*}{$\begin{array}{l}\text { Elem. Form. } \\
\text { (Mol. Weight) }\end{array}$} & \multicolumn{4}{|c|}{ Elem. Anal. (\%) } \\
\hline & & & & & & & $\mathrm{C}$ & $\mathrm{H}$ & $\mathrm{N}$ \\
\hline \multirow[t]{2}{*}{$5 a^{b}$} & $1.0: 0$ & 82 & 17100 & 3.60 & $\left(\mathrm{C}_{60} \mathrm{H}_{75} \mathrm{~N}_{30} \mathrm{O}_{10}\right)_{n}$ & Calc. & 72.19 & 7.57 & 4.21 \\
\hline & & & & & $(998.3)_{n}$ & Found & 72.01 & 7.56 & 4.12 \\
\hline \multirow[t]{2}{*}{$5 \mathbf{b}$} & 0.8:0.2 & 78 & 17200 & 3.49 & $\left(\mathrm{C}_{60.2} \mathrm{H}_{75.6} \mathrm{~N}_{2.8} \mathrm{O}_{9.8}\right)_{n}$ & Calc. & 72.65 & 7.66 & 3.98 \\
\hline & & & & & $(995.3)_{n}$ & Found & 72.89 & 7.80 & 3.88 \\
\hline \multirow[t]{2}{*}{$5 c$} & 0.6:0.4 & 83 & 13300 & 2.22 & $\left(\mathrm{C}_{60.4} \mathrm{H}_{76.2} \mathrm{~N}_{2.6} \mathrm{O}_{9.6}\right)_{n}$ & Calc. & 73.11 & 7.74 & 3.67 \\
\hline & & & & & $(992.3)_{n}$ & Found & 73.36 & 7.95 & 3.61 \\
\hline \multirow[t]{2}{*}{$5 d$} & $0.5: 0.5$ & 87 & 20300 & 3.42 & $\left(\mathrm{C}_{60.5} \mathrm{H}_{76.5} \mathrm{~N}_{2.5} \mathrm{O}_{9.5}\right)_{n}$ & Calc. & 73.34 & 7.78 & 3.53 \\
\hline & & & & & $(990.8)_{n}$ & Found & 73.35 & 7.78 & 3.48 \\
\hline \multirow[t]{2}{*}{$5 e$} & $0.4: 0.6$ & 83 & 17100 & 2.66 & $\left(\mathrm{C}_{60.6} \mathrm{H}_{76.8} \mathrm{~N}_{2.4} \mathrm{O}_{9.4}\right)_{n}$ & Calc. & 73.57 & 7.83 & 3.40 \\
\hline & & & & & $(989.3)_{n}$ & Found & 73.58 & 7.78 & 3.32 \\
\hline \multirow[t]{2}{*}{$5 f$} & $0.2: 0.8$ & 71 & 11400 & 2.15 & $\left(\mathrm{C}_{60.8} \mathrm{H}_{77.4} \mathrm{~N}_{2.2} \mathrm{O}_{9.2}\right)_{n}$ & Calc. & 74.04 & 7.98 & 3.12 \\
\hline & & & & & $(996.3)_{n}$ & Found & 74.12 & 7.92 & 3.29 \\
\hline \multirow[t]{2}{*}{$5 g^{b}$} & $0: 1.0$ & 86 & 21600 & 2.10 & $\left(\mathrm{C}_{61} \mathrm{H}_{78} \mathrm{~N}_{2} \mathrm{O}_{9}\right)_{n}$ & Calc. & 74.51 & 8.00 & 2.85 \\
\hline & & & & & $(983.3)_{n}$ & Found & 74.37 & 7.97 & 2.84 \\
\hline
\end{tabular}

${ }^{\mathrm{a}} M_{\mathrm{n}}$ : Number-average molecular weights, $M_{\mathrm{w}} / M_{\mathrm{n}}$ : molecular-weight distributions. Measured in chloroform using as a standard at room temperature. ${ }^{\text {b}}$ Our previously-reported data. ${ }^{20}$

Table II. Synthetic results for polyesters $\mathbf{6 a}-\mathbf{g}$

\begin{tabular}{|c|c|c|c|c|c|c|c|c|c|}
\hline \multirow{2}{*}{ Polym. } & \multirow{2}{*}{$x: y$} & \multirow{2}{*}{$\begin{array}{l}\text { Yield } \\
(\%)\end{array}$} & \multirow{2}{*}{$M_{\mathrm{n}}{ }^{\mathrm{a}}$} & \multirow{2}{*}{$M_{\mathrm{w}} / M_{\mathrm{n}}{ }^{\mathrm{a}}$} & \multirow{2}{*}{$\begin{array}{l}\text { Elem. Form. } \\
\text { (Mol. Weight) }\end{array}$} & \multicolumn{4}{|c|}{ Elem. Anal. (\%) } \\
\hline & & & & & & & $\mathrm{C}$ & $\mathrm{H}$ & $\mathrm{N}$ \\
\hline \multirow[t]{2}{*}{$6 \mathbf{a}$} & \multirow[t]{2}{*}{ 1.0:0 } & \multirow[t]{2}{*}{80} & \multirow[t]{2}{*}{14300} & \multirow[t]{2}{*}{3.93} & \multirow{2}{*}{$\begin{array}{c}\left(\mathrm{C}_{62} \mathrm{H}_{79} \mathrm{~N}_{3} \mathrm{O}_{10}\right)_{n} \\
(1026.3)_{n}\end{array}$} & Calc. & 72.56 & 7.76 & 4.09 \\
\hline & & & & & & Found & 72.37 & 7.64 & 3.84 \\
\hline \multirow[t]{2}{*}{$6 b$} & \multirow[t]{2}{*}{$0.8: 0.2$} & \multirow[t]{2}{*}{70} & \multirow[t]{2}{*}{14100} & \multirow[t]{2}{*}{4.40} & \multirow{2}{*}{$\begin{array}{c}\left(\mathrm{C}_{62.2} \mathrm{H}_{79.6} \mathrm{~N}_{2.8} \mathrm{O}_{9.8}\right)_{n} \\
(1023.3)_{n}\end{array}$} & Calc. & 73.01 & 7.84 & 3.83 \\
\hline & & & & & & Found & 72.71 & 7.72 & 3.80 \\
\hline \multirow[t]{2}{*}{$6 c$} & \multirow[t]{2}{*}{$0.6: 0.4$} & \multirow[t]{2}{*}{76} & \multirow[t]{2}{*}{15000} & \multirow[t]{2}{*}{3.33} & \multirow{2}{*}{$\begin{array}{c}\left(\mathrm{C}_{64.8} \mathrm{H}_{80.2} \mathrm{~N}_{2.6} \mathrm{O}_{9.6}\right)_{n} \\
(1049.2)_{n}\end{array}$} & Calc. & 74.18 & 7.71 & 3.47 \\
\hline & & & & & & Found & 73.23 & 7.80 & 3.57 \\
\hline \multirow[t]{2}{*}{ 6d } & \multirow[t]{2}{*}{$0.5: 0.5$} & \multirow[t]{2}{*}{79} & \multirow[t]{2}{*}{16800} & \multirow[t]{2}{*}{3.67} & \multirow{2}{*}{$\begin{array}{c}\left(\mathrm{C}_{62.5} \mathrm{H}_{80.5} \mathrm{~N}_{2.5} \mathrm{O}_{9.5}\right)_{n} \\
(1018.8)_{n}\end{array}$} & Calc. & 73.68 & 7.96 & 3.44 \\
\hline & & & & & & Found & 73.23 & 7.82 & 3.44 \\
\hline \multirow[t]{2}{*}{$6 e$} & \multirow[t]{2}{*}{$0.4: 0.6$} & \multirow[t]{2}{*}{71} & \multirow[t]{2}{*}{16700} & \multirow[t]{2}{*}{3.35} & $\left(\mathrm{C}_{64.2} \mathrm{H}_{80.8} \mathrm{~N}_{2.4} \mathrm{O}_{9.4}\right)_{n}$ & Calc. & 74.39 & 7.86 & 3.24 \\
\hline & & & & & (100) & Found & 74.03 & 7.87 & 3.04 \\
\hline $6 f$ & $0.2: 0.8$ & 76 & 17900 & 3.01 & $\left(\mathrm{C}_{63.8} \mathrm{H}_{81.4} \mathrm{~N}_{2.2} \mathrm{O}_{9.2}\right)_{n}$ & Calc. & 74.60 & 8.01 & 3.01 \\
\hline & & & & & $(1024.0)_{n}$ & Found & 74.32 & 7.96 & 3.06 \\
\hline $6 \mathrm{~g}$ & $0: 1.0$ & 73 & 17800 & 2.41 & $\left(\mathrm{C}_{63} \mathrm{H}_{82} \mathrm{~N}_{2} \mathrm{O}_{9}\right)_{n}$ & Calc. & 74.82 & 8.17 & 2.77 \\
\hline & & & & & $(1011.4)_{n}$ & Found & 74.68 & 8.06 & 2.53 \\
\hline
\end{tabular}

${ }^{\mathrm{a}} M_{\mathrm{n}}$ : Number-average molecular weights, $M_{\mathrm{w}} / M_{\mathrm{n}}$ : molecular-weight distributions. Measured in chloroform using polystyrene as a standard at room temperature.

\section{RESULTS AND DISCUSSION}

\section{Polymer Syntheses}

Polyisophthalates $\mathbf{5 b}-\mathbf{f}, \mathbf{6 a}-\mathbf{g}$ and $\mathbf{7 b}-\mathbf{f}$ except for homopolyisophthalates $5 \mathbf{a}, \mathbf{5 g}, \mathbf{7 a}$ and $\mathbf{7 g}$ reported in our previous paper were prepared from a mixture of isophthalate monomers 3a-6, 3a-8, 3a-10, 3b-6, $\mathbf{3 b - 8}$ and $\mathbf{3 b - 1 0}$ of azobenzenes and dioxydiundecanol 4 of biphenyl taken in various feed mole ratios in the presence of zinc acetate by melt polycondensation according to our published procedure. ${ }^{20}$ The synthetic results are listed in Tables I-III, which show that number average molecular weights $\left(M_{\mathrm{n}}\right)$ and molecular weight distributions $\left(M_{\mathrm{w}} / M_{\mathrm{n}}\right)$ of the polymers are 11400-20300 and 2.15-5.02, respectively. The polymers, which were yellow-to-orange solids obtained in yields of $70-86 \%$, were soluble in common organic solvents like chloroform and dichloroacetic acid (DCAA) at room temperature and flexible films were able to be cast from the chloroform solutions. The assigned structures of polymers were characterized by ${ }^{1} \mathrm{H}$ NMR and FT IR spectra, and elemental analyses. The ${ }^{1} \mathrm{H}$ NMR and FT IR spectra of polymers $\mathbf{5 b}-\mathbf{f}, \mathbf{6} \mathbf{a}-\mathbf{g}$ and $\mathbf{7 b}-\mathbf{f}$ were similar to those of our previously-reported polyesters ${ }^{20}$ and suggest that the desired polyisophthalates are successfully obtained. Typical ${ }^{1} \mathrm{H}$ NMR spectrum of copolyester $\mathbf{6 e}$ in $\mathrm{CDCl}_{3}$ is shown in Figure 1, where proton signals for benzene rings at $6.91-8.37 \mathrm{ppm},-\mathrm{OCH}_{2}-$ at 
Relationships between Structures and Liquid Crystalline and Optical Properties in Combined-type Copolyisophthalates

Table III. Synthetic results for polyesters $7 \mathbf{a}-\mathbf{g}$

\begin{tabular}{|c|c|c|c|c|c|c|c|c|c|}
\hline \multirow{2}{*}{ Polym. } & \multirow{2}{*}{$x: y$} & \multirow{2}{*}{$\begin{array}{l}\text { Yield } \\
(\%)\end{array}$} & \multirow{2}{*}{$M_{\mathrm{n}}{ }^{\mathrm{a}}$} & \multirow{2}{*}{$M_{\mathrm{w}} / M_{\mathrm{n}}{ }^{\mathrm{a}}$} & \multirow{2}{*}{$\begin{array}{l}\text { Elem. Form. } \\
\text { (Mol. Weight) }\end{array}$} & \multicolumn{4}{|c|}{ Elem. Anal. (\%) } \\
\hline & & & & & & & $\mathrm{C}$ & $\mathrm{H}$ & $\mathrm{N}$ \\
\hline \multirow[t]{2}{*}{$7 a^{b}$} & \multirow[t]{2}{*}{$1.0: 0$} & \multirow[t]{2}{*}{79} & \multirow[t]{2}{*}{18100} & \multirow[t]{2}{*}{3.70} & \multirow{2}{*}{$\begin{array}{c}\left(\mathrm{C}_{64} \mathrm{H}_{83} \mathrm{~N}_{3} \mathrm{O}_{10}\right)_{n} \\
(1054.4)_{n}\end{array}$} & Calc. & 72.91 & 7.93 & 3.99 \\
\hline & & & & & & Found & 73.03 & 8.05 & 4.06 \\
\hline \multirow[t]{2}{*}{$7 b$} & \multirow[t]{2}{*}{$0.8: 0.2$} & \multirow[t]{2}{*}{86} & \multirow[t]{2}{*}{14100} & \multirow[t]{2}{*}{5.02} & \multirow{2}{*}{$\begin{array}{c}\left(\mathrm{C}_{64.2} \mathrm{H}_{83.6} \mathrm{~N}_{2.8} \mathrm{O}_{9.8}\right)_{n} \\
(1050.8)_{n}\end{array}$} & Calc. & 73.38 & 8.02 & 3.73 \\
\hline & & & & & & Found & 72.72 & 7.63 & 3.28 \\
\hline \multirow[t]{2}{*}{$7 \mathrm{c}$} & \multirow[t]{2}{*}{$0.6: 0.4$} & \multirow[t]{2}{*}{76} & \multirow[t]{2}{*}{17100} & \multirow[t]{2}{*}{3.24} & \multirow{2}{*}{$\begin{array}{c}\left(\mathrm{C}_{64.4} \mathrm{H}_{84.2} \mathrm{~N}_{2.6} \mathrm{O}_{9.6}\right)_{n} \\
(1048.4)_{n}\end{array}$} & Calc. & 73.78 & 8.10 & 3.47 \\
\hline & & & & & & Found & 73.01 & 7.86 & 3.07 \\
\hline \multirow[t]{2}{*}{$7 d$} & \multirow[t]{2}{*}{$0.5: 0.5$} & \multirow[t]{2}{*}{77} & \multirow[t]{2}{*}{19000} & \multirow[t]{2}{*}{2.92} & \multirow{2}{*}{$\begin{array}{c}\left(\mathrm{C}_{64.5} \mathrm{H}_{84.5} \mathrm{~N}_{2.5} \mathrm{O}_{9.5}\right)_{n} \\
(1046.9)_{n}\end{array}$} & Calc. & 74.00 & 8.14 & 3.34 \\
\hline & & & & & & Found & 74.21 & 8.21 & 3.38 \\
\hline \multirow[t]{2}{*}{$7 e$} & \multirow[t]{2}{*}{$0.4: 0.6$} & \multirow[t]{2}{*}{75} & \multirow[t]{2}{*}{16400} & \multirow[t]{2}{*}{3.29} & $\left(\mathrm{C}_{64.6} \mathrm{H}_{84.8} \mathrm{~N}_{2.4} \mathrm{O}_{9.4}\right)_{n}$ & Calc. & 74.16 & 8.18 & 3.22 \\
\hline & & & & & $(1045.4)_{n}$ & Found & 73.15 & 7.95 & 2.99 \\
\hline $7 f$ & $0.2: 0.8$ & 79 & 17900 & 3.13 & $\left(\mathrm{C}_{64.8} \mathrm{H}_{85.4} \mathrm{~N}_{2.2} \mathrm{O}_{9.2}\right)_{n}$ & Calc. & 74.67 & 8.26 & 2.96 \\
\hline & & & & & $(1039.4)_{n}$ & Found & 73.90 & 8.05 & 2.59 \\
\hline $7 \mathrm{~g}^{\mathrm{b}}$ & $0: 1.0$ & 75 & 16000 & 2.11 & $\left(\mathrm{C}_{65} \mathrm{H}_{86} \mathrm{~N}_{2} \mathrm{O}_{9}\right)_{n}$ & Calc. & 75.11 & 8.34 & 2.70 \\
\hline & & & & & $(1039.4)_{n}$ & Found & 74.52 & 8.27 & 2.74 \\
\hline
\end{tabular}

${ }^{\mathrm{a}} M_{\mathrm{n}}$ : Number-average molecular weights, $M_{\mathrm{w}} / M_{\mathrm{n}}$ : molecular-weight distributions. Measured in chloroform using polystyrene as a standard at room temperature. ${ }^{\mathrm{b}}$ Our previously-reported data. ${ }^{20}$

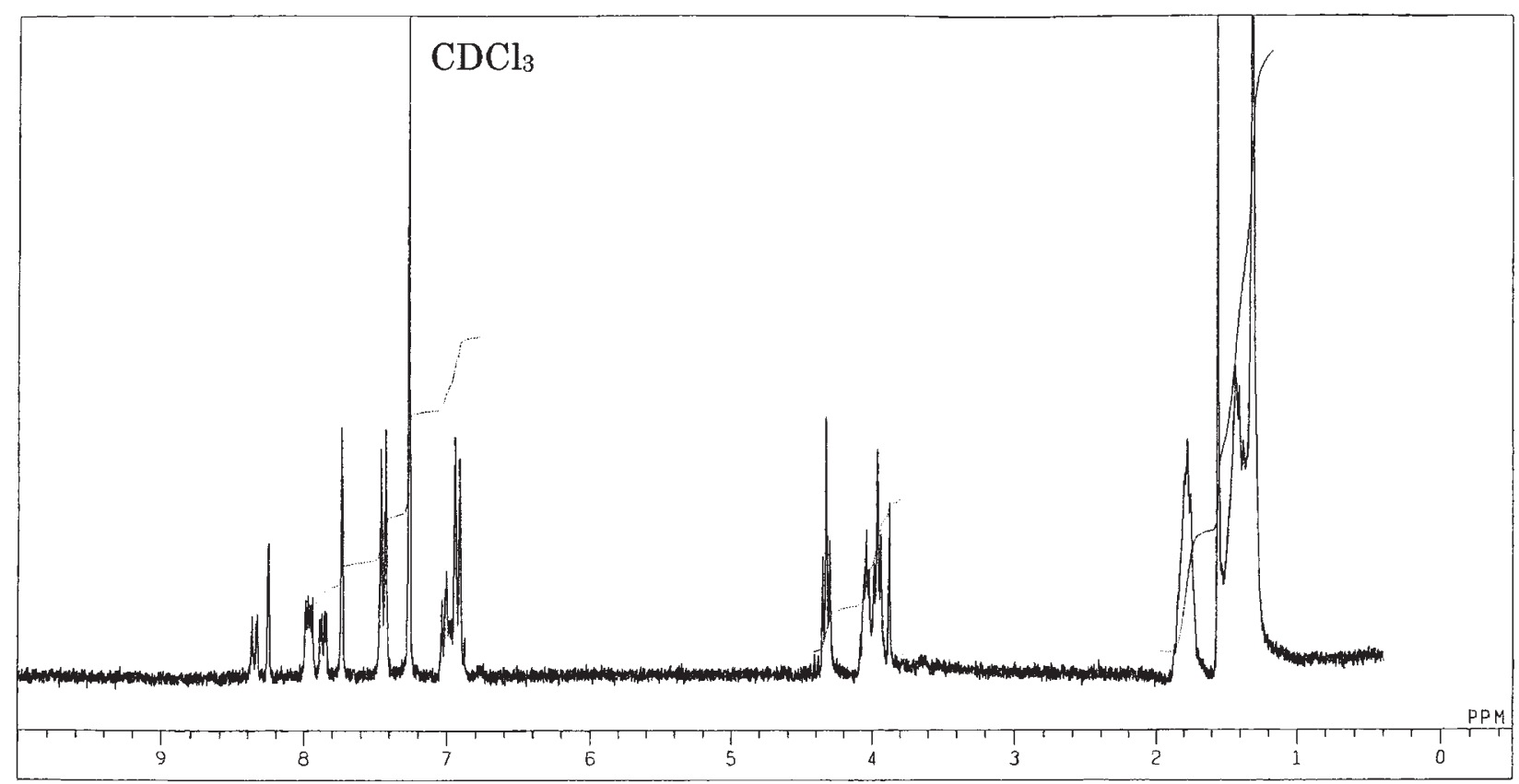

Figure 1. ${ }^{1} \mathrm{H}$ NMR spectrum of copolyester $\mathbf{6 e}$ in $\mathrm{CDCl}_{3}$.

$3.96 \mathrm{ppm},-\mathrm{C}(\mathrm{O}) \mathrm{OCH}_{2}-$ at $4.32 \mathrm{ppm},-\mathrm{OCH}_{3}$ at $3.87 \mathrm{ppm}$ and $-\left(\mathrm{CH}_{2}\right)_{m}$ - chains at $1.31-1.77 \mathrm{ppm}$ were observed. In the FT IR spectra, characteristic absorption bands based on azobenzene unit near $1600 \mathrm{~cm}^{-1}$ and ester linkage at around $1722 \mathrm{~cm}^{-1}$ were recognized together with those of $\mathrm{CH}$ stretching at 2852$2927 \mathrm{~cm}^{-1}, \mathrm{C}-\mathrm{O}-\mathrm{C}$ linkage at $1238-1242 \mathrm{~cm}^{-1}$ and nitro group at 1523 and $1340 \mathrm{~cm}^{-1}$. The elemental analysis data for expected polymers are in very good agreement with the calculated ones. These data confirm the production of polyesters $5 \mathbf{b}-\mathbf{f}, \mathbf{6} \mathbf{a}-\mathbf{g}$ and $7 b-f$.

\section{Mesomorphic Properties}

Our previously-reported paper $^{20}$ described that combined-type homopolyisophthalates $\mathbf{5 a}, \mathbf{5 g}, \mathbf{7 a}$ and $\mathbf{7 g}$ having the side-chain nitro- or methoxyazobenzene unit form smectic $\mathrm{B}, \mathrm{C}$ or $\mathrm{E}$ phase in spite of the presence of different mesogenic moieties both in the main chain and in the side chain. It has been reported that multiple-step process from smectic to isotropic transitions occurs in combined-type polymalonates having the methoxyazobenzene unit by Ringsdorf et al. ${ }^{2,21}$ In very recent years, polyketones bearing side-chain azobenzene unit were disclosed to 
form smectic LC phase. ${ }^{29}$ In this way, many sidechain or combined-type polymers having the azobenzene moieties exhibit smectic phases.

In this work, thermotropic LC properties of homoand copolyisophthalates $\mathbf{5 b}-\mathbf{f}, \mathbf{6 a}-\mathbf{g}$ and $\mathbf{7 b}-\mathbf{f}$ were examined by means of DSC measurements, optical texture observations by using a polarizing microscope and powder X-Ray diffraction in order to disclose relationship between polymer structure and smectic LC property in combined-type polyisophthalates in more detail. It is of interest how coexistence of side-chain electron-withdrawing (nitro) and electron-donating (methoxy) groups and aliphatic spacers with different chain lengths ( $m=6,8$ and 10) in the polymer chains affect formation of smectic ordered phases.

Phase Transition Behaviors and LC Textures. In the DSC curves of homo- and copolyisophthalates 5a-g, 6a- $-\mathbf{g}$ and $7 \mathbf{a}-\mathbf{g}$ on the first and the second heating runs, two or three endothermal peaks based on solid-to-solid $\left(T_{\mathrm{k}}\right)$ at $61^{\circ} \mathrm{C}(\mathbf{5 g}), 68^{\circ} \mathrm{C}(\mathbf{6 b})$ and $91^{\circ} \mathrm{C}$ $(\mathbf{7 g})$, solid-to-LC phase $\left(T_{\mathrm{m}}\right)$ at $68-108^{\circ} \mathrm{C}(\mathbf{5 a}-\mathbf{g})$, $77-128^{\circ} \mathrm{C}(\mathbf{6 a}-\mathbf{g})$ and $74-93^{\circ} \mathrm{C}(\mathbf{7 a}-\mathbf{g})$ and $\mathrm{LC}$ phase-to-isotropization $\left(T_{\mathrm{i}}\right)$ at $131-143^{\circ} \mathrm{C}(\mathbf{5 a}-\mathbf{g})$, $134-141^{\circ} \mathrm{C}(\mathbf{6 a}-\mathbf{g})$ and $133-141^{\circ} \mathrm{C}(\mathbf{7 a}-\mathbf{g})$ together with glass transition $\left(T_{\mathrm{g}}\right)$ steps at $40-43{ }^{\circ} \mathrm{C}(\mathbf{5 a}-\mathbf{g})$, $41-60{ }^{\circ} \mathrm{C}(\mathbf{6} \mathbf{a}-\mathbf{g})$ and $47-54^{\circ} \mathrm{C}(\mathbf{7} \mathbf{a}-\mathbf{g})$ were observed in most of the polymers. The transition enthalpies $\left(\Delta H_{\mathrm{m}}\right.$ and $\left.\Delta H_{\mathrm{i}}\right)$ were $0.14-21.3 \mathrm{~J} \mathrm{~g}^{-1}$ and 13.4 $22.5 \mathrm{~J} \mathrm{~g}^{-1}$, respectively. On the first cooling scans, the corresponding two exothermal peaks on the basis of $T_{i}$ and LC phase-to-solid $\left(T_{\mathrm{c}}\right)$ transitions were detectable.

Typical DSC curves for homo- and copolyesters $\mathbf{7 a -}-\mathbf{g}$ are shown in Figure 2. The phase transition data of polymers $5 \mathbf{a}-\mathbf{g}, \mathbf{6 a}-\mathbf{g}$ and $7 \mathbf{a}-\mathbf{g}$ on the second heating runs are listed in Table IV together with the data reported in our previous paper, ${ }^{20}$ which reveals that the phase transition temperatures $\left(T_{\mathrm{m}}\right.$ and $\left.T_{\mathrm{i}}\right)$ of copolymers $\mathbf{5 b}-\mathbf{f}, \mathbf{6 b}-\mathbf{f}$ and $\mathbf{7 b}-\mathbf{f}$ change linearly with the copolymer composition independent of the aliphatic chain lengths in the side chains. The homopolymers having electron-withdrawing group 5a, 6a and 7a have wider LC temperature ranges $(\Delta T)$ than those for electron-donating group $\mathbf{5 g}, \mathbf{6 g}$ and $\mathbf{7 g}$. The Tms tend to increase with increasing the methoxyazobenzene content, and the $T_{i} \mathrm{~s}$ and the $\Delta T_{\mathrm{s}}$ decrease reversely. Relationship between copolymer composition and phase tansition temperature in homo- and copolymers 7a-g with the side-chain decamethylene spacer are presented in Figure 3. The polarizing microscope observations showed that all the polymers form enantiotropic thermotropic fine texture between $T_{\mathrm{m}}\left(T_{\mathrm{c}}\right)$ and $T_{\mathrm{i}}$ on heating and cooling. Figure 4 shows a polarizing microphotograph of polymer $7 \mathbf{e}$ at $130^{\circ} \mathrm{C}$ on cooling.

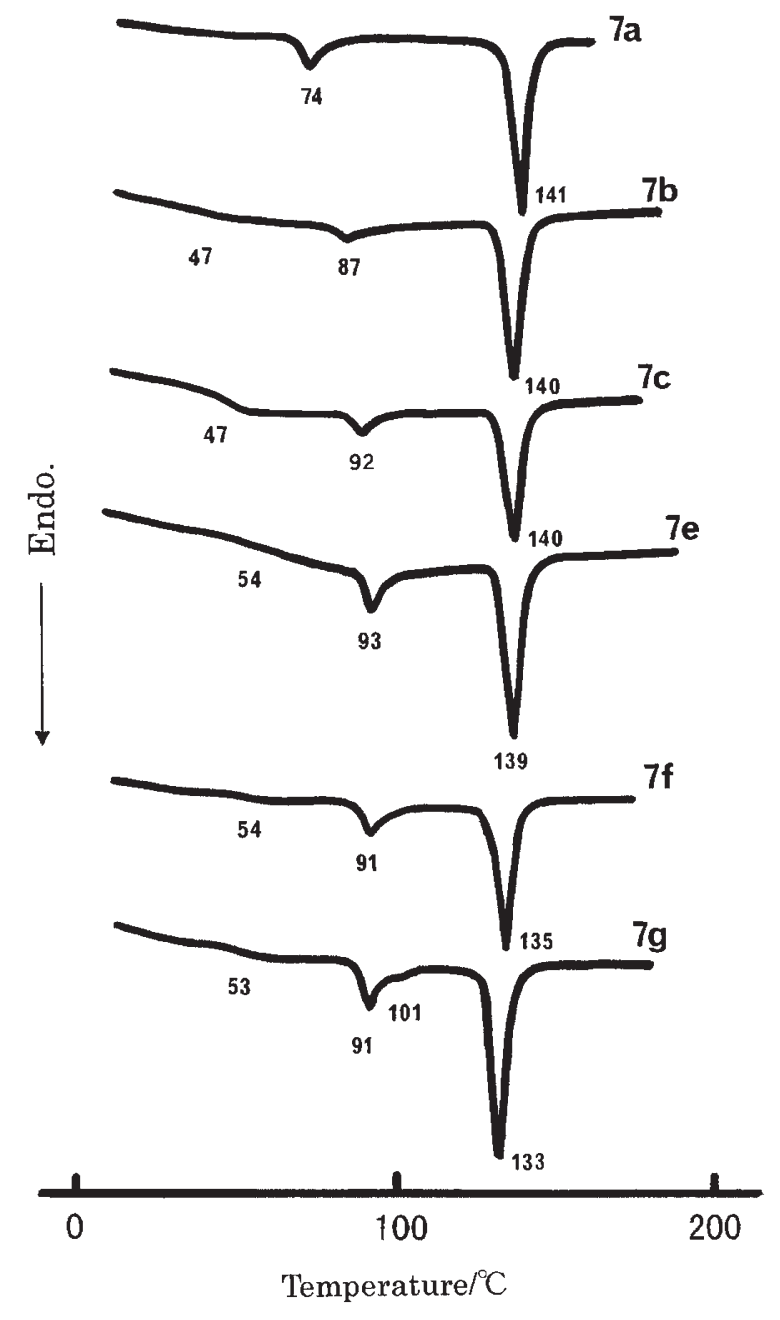

Figure 2. DSC curves of homo- and copolyesters $7 \mathbf{a}-\mathbf{g}$ on the second heating runs.

X-Ray Analyses. The powder X-Ray diffraction patterns and the data of X-Ray reflections at middle and wide angles (Table V) of polymers $5 \mathbf{a}-\mathbf{g}, \mathbf{6 a}-\mathbf{g}$ and $7 \mathbf{a}-\mathbf{g}$ quenched from the LC states indicate that the homo- and copolyisophthalates 5a-g, 6a-g and 7a-g form thermotropic LC smectic (B, C or E) phase, in which the first and the second order sharp reflections at middle angles $\left(\mathbf{5 a}-\mathbf{g}: 2 \theta=2.52-2.80^{\circ}\right.$ and $5.12-5.68^{\circ}, 6 \mathbf{6}-\mathrm{g}: 2 \theta=2.40-2.69^{\circ}$ and $4.90-5.40^{\circ}$, 7a-g: $2 \theta=2.30-2.52^{\circ}$ and $4.72-5.15^{\circ}$ ) and sharp or broad reflections at wide angles $(\mathbf{5 a}-\mathbf{g}: 2 \theta=$ $20.3-28.2^{\circ}, \quad \mathbf{6 a}-\mathbf{g}: \quad 2 \theta=20.2-24.5^{\circ} ; \quad 7 \mathbf{a}-\mathbf{g}: 2 \theta=$ $20.2-22.2^{\circ}$ ) are found. The X-Ray diffraction patterns of polymers $6 \mathbf{6}-\mathbf{g}$ are shown in Figure 5. The homopolymer $6 \mathbf{g}$ shows broad reflection at around $2 \theta=15-30^{\circ}$ and two sharp (the first $\left(2 \theta=2.66^{\circ}\right)$ and the second $\left.\left(2 \theta=5.16^{\circ}\right)\right)$ reflections at middle angles, which is similar to that of previously-reported polymer 5g forming smectic $\mathrm{C}$ phase. In the homopolymer 6a, three sharp reflections were recognized at $2 \theta=20.2-24.5^{\circ}$ together with the sharp reflections at middle angles $\left(2 \theta=2.42\right.$ and $\left.4.90^{\circ}\right)$. This X-Ray 
Relationships between Structures and Liquid Crystalline and Optical Properties in Combined-type Copolyisophthalates

Table IV. Phase transition data of polyesters $5 \mathbf{a}-\mathbf{g}, \mathbf{6 a}-\mathbf{g}$ and $\mathbf{7 a}-\mathbf{g}$ for DSC curves on the second heating runs ${ }^{\mathrm{a}}$

\begin{tabular}{ccccccccc}
\hline Polym. & $\begin{array}{c}T_{\mathrm{g}} \\
\left({ }^{\circ} \mathrm{C}\right)\end{array}$ & $\begin{array}{c}T_{\mathrm{k}} \\
\left({ }^{\circ} \mathrm{C}\right)\end{array}$ & $\begin{array}{c}T_{\mathrm{m}} \\
\left({ }^{\circ} \mathrm{C}\right)\end{array}$ & $\begin{array}{c}\Delta H_{\mathrm{m}} \\
(\mathrm{J} / \mathrm{g})\end{array}$ & $\begin{array}{c}T_{\mathrm{i}} \\
\left({ }^{\circ} \mathrm{C}\right)\end{array}$ & $\begin{array}{r}\Delta H_{\mathrm{i}} \\
(\mathrm{J} / \mathrm{g})\end{array}$ & $\begin{array}{c}\Delta T \\
\left({ }^{\circ} \mathrm{C}\right)\end{array}$ & LC phase \\
\hline $\mathbf{5 a} \mathbf{a}^{\mathrm{b}}$ & & & 68 & 3.29 & 143 & 17.9 & 75 & Smectic E \\
$\mathbf{5 b}$ & 40 & & 69 & 0.14 & 143 & 18.0 & 74 & Smectic B \\
$\mathbf{5 c}$ & 40 & & 72 & 0.49 & 141 & 19.8 & 69 & Smectic B \\
$\mathbf{5 d}$ & 43 & & 70 & 0.46 & 140 & 17.4 & 70 & Smectic B \\
$\mathbf{5 e}$ & 43 & & 73 & 0.35 & 140 & 18.0 & 67 & Smectic B \\
$\mathbf{5 f}$ & 40 & & 98 & 6.68 & 131 & 14.6 & 33 & Smectic B \\
$\mathbf{5 g}$ & & 61 & 108 & 21.3 & 133 & 14.9 & 25 & Smectic C \\
$\mathbf{6 a}$ & & & 77 & 3.60 & 141 & 17.4 & 64 & Smectic E \\
$\mathbf{6 b}$ & & 68 & 81 & 0.94 & 140 & 18.1 & 59 & Smectic B \\
$\mathbf{6 c}$ & 41 & & 84 & 0.91 & 140 & 17.6 & 56 & Smectic B \\
$\mathbf{6 d}$ & 43 & & 85 & 1.72 & 140 & 17.7 & 55 & Smectic B \\
$\mathbf{6 e}$ & 50 & & 86 & 1.51 & 139 & 22.5 & 53 & Smectic B \\
$\mathbf{6 f}$ & 51 & $107^{\mathrm{c}}$ & 123 & 7.64 & 137 & 13.4 & 14 & Smectic B \\
$\mathbf{6 g}$ & 60 & & 128 & 8.39 & 134 & 8.33 & 6 & Smectic C \\
$\mathbf{7 a}{ }^{\mathrm{b}}$ & & & 74 & 3.11 & 141 & 20.1 & 67 & Smectic E \\
$\mathbf{7 b}$ & 47 & & 87 & 1.20 & 140 & 18.6 & 53 & Smectic B \\
$\mathbf{7 c}$ & 47 & & 92 & 1.91 & 140 & 18.2 & 48 & Smectic B \\
$\mathbf{7 d}$ & 49 & & 91 & 2.66 & 140 & 20.1 & 49 & Smectic B \\
$\mathbf{7 e}$ & 54 & & 93 & 2.89 & 139 & 21.3 & 46 & Smectic B \\
$\mathbf{7 f}$ & 54 & & 91 & 4.36 & 135 & 18.2 & 44 & Smectic B \\
$\mathbf{7 g}$ & 53 & 91 & 101 & $1.0>$ & 133 & 18.3 & 32 & Smectic B \\
\hline
\end{tabular}

${ }^{\mathrm{a}} T_{\mathrm{g}}$ : Glass transition temperature, $T_{\mathrm{k}}$ : solid-to-solid transition temperature, $T_{\mathrm{m}}$ : solid-to-smectic phase transition temperature, $T_{\mathrm{i}}$ : smectic phase-to-isotropization transition temperature, $\Delta T=T_{\mathrm{i}}-T_{\mathrm{m}}$ : temperature range of smectic phase, $\Delta H_{\mathrm{m}}$ : transition enthalpy for $T_{\mathrm{m}}, \Delta H_{\mathrm{i}}$ : transition enthalpy for $T_{\mathrm{i}}$. ${ }^{\mathrm{b}}$ Our previously-reported data. ${ }^{20}$ Cold crystallization.

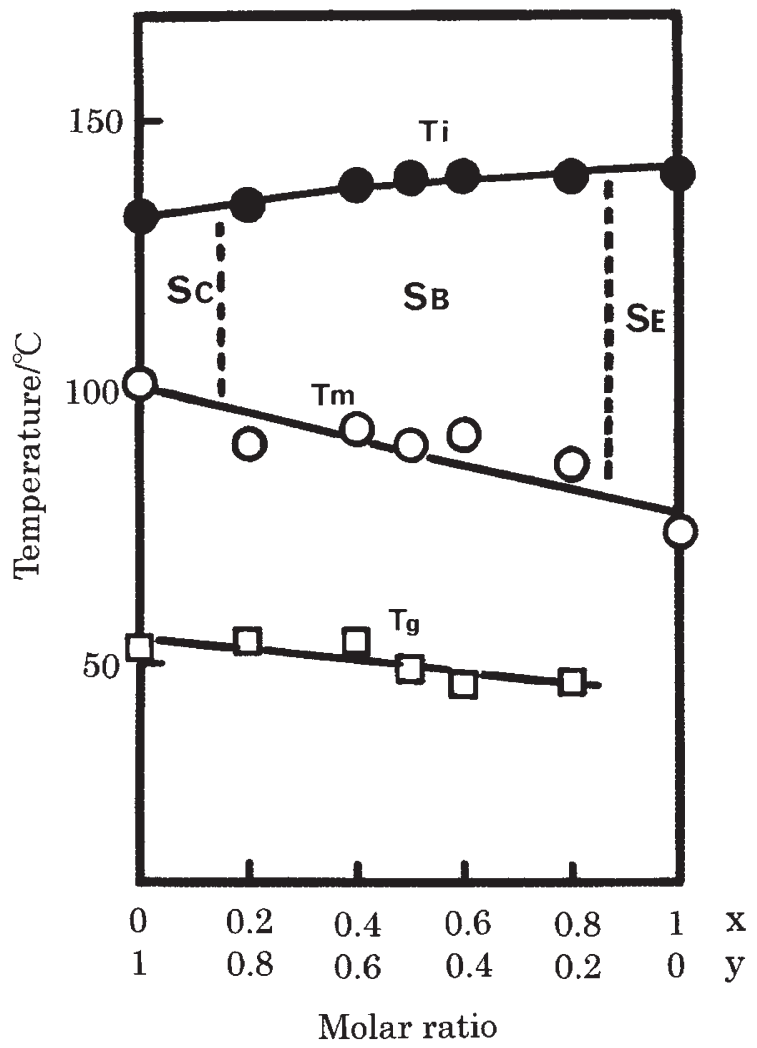

Figure 3. Relationship between copolymer composition and phase tansition temperature in polyesters $\mathbf{7 a - g}$.

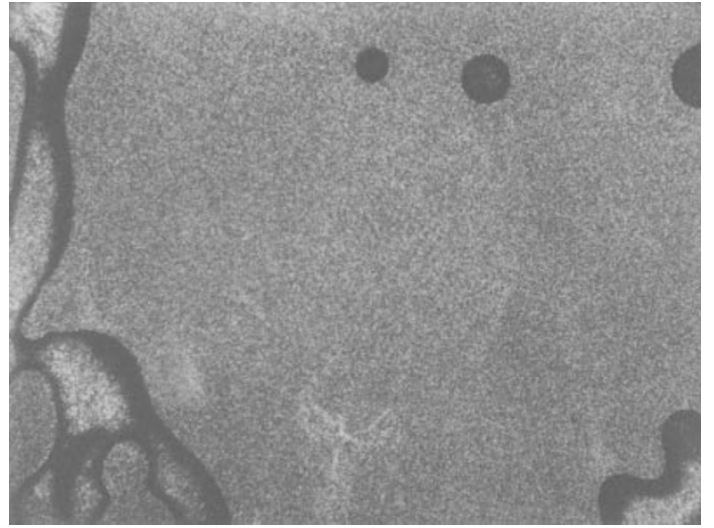

Figure 4. Polarizing microphtograph of copolyester 7e at $130{ }^{\circ} \mathrm{C}$ on cooling (magnification: $\times 200$ ).

diffraction pattern is generally considered to be due to the smectic E phase as observed in homopolymers 5a and $7 \mathbf{a}$.

In the copolymers $\mathbf{5 b}-\mathbf{f}, \mathbf{6 b}-\mathbf{f}$ and $\mathbf{7 b}-\mathbf{f}$, all the copolyesters show the X-Ray diffraction patterns for smectic B phase, independent of the copolymer composition and the chain length of aliphatic spacer in the side chain, as well as the homopolyisophthalate $\mathbf{7 g}$, where one or two sharp reflections at middle angles $\left(2 \theta=2.30-2.67^{\circ}\right.$ and $\left.4.72-5.51^{\circ}\right)$ and sharp reflec- 
Table V. Data of X-Ray reflections for polyesters $5 \mathbf{a}-\mathbf{g}, \mathbf{6} \mathbf{a}-\mathbf{g}$ and $7 \mathbf{a}-\mathbf{g}$ quenched from mesophases

\begin{tabular}{cllc}
\hline \multirow{2}{*}{ Polym. } & \multicolumn{2}{c}{ Small angle } & $\begin{array}{c}\text { Wide angle } \\
2 \theta /{ }^{\circ}\end{array}$ \\
\cline { 2 - 4 } & \multicolumn{1}{c}{$2 \theta /^{\circ}$} & \multicolumn{1}{c}{$d$-spacing $/ \AA$} & $20.3,22.5,28.2$ \\
\hline $\mathbf{5 a}$ & $2.54,5.12$ & $34.7,17.2$ & 20.8 \\
$\mathbf{5 b}$ & $2.52,5.21$ & $35.1,16.9$ & 20.7 \\
$\mathbf{5 c}$ & 2.59 & 34.1 & 21.0 \\
$\mathbf{5 d}$ & $2.74,5.51$ & $32.2,16.0$ & 20.5 \\
$\mathbf{5 e}$ & 2.68 & 33.0 & 21.4 \\
$\mathbf{5 f}$ & $2.76,5.30$ & $31.9,16.7$ & 21.8 \\
$\mathbf{5 g}$ & $2.80,5.68$ & $31.6,15.6$ & $20.2,22.4,24.5$ \\
$\mathbf{6 a}$ & $2.42,4.90$ & $36.5,18.0$ & 20.8 \\
$\mathbf{6 b}$ & $2.40,4.92$ & $36.7,18.0$ & 20.8 \\
$\mathbf{6 c}$ & $2.56,5.08$ & $34.5,17.4$ & 20.8 \\
$\mathbf{6 d}$ & $2.52,5.11$ & $35.0,17.3$ & 20.7 \\
$\mathbf{6 e}$ & $2.63,5.34$ & $33.5,16.5$ & 20.7 \\
$\mathbf{6 f}$ & $2.69,5.40$ & $32.8,16.3$ & 22.5 \\
$\mathbf{6 g}$ & $2.66,5.16$ & $33.1,17.1$ & 22.2 \\
$\mathbf{7 a}$ & $2.34,4.75$ & $37.7,18,6$ & 20.8 \\
$\mathbf{7 b}$ & $2.30,4.72$ & $38.4,18.7$ & 20.8 \\
$\mathbf{7 c}$ & $2.30,4.77$ & $38.4,18.5$ & 20.9 \\
$\mathbf{7 d}$ & $2.50,4.90$ & $35.3,18.0$ & 20.7 \\
$\mathbf{7 e}$ & $2.40,4.87$ & $36.8,18.1$ & 20.7 \\
$\mathbf{7 f}$ & $2.45,5.05$ & $36.1,17.5$ & 20.9 \\
$\mathbf{7 g}$ & $2.52,5.15$ & $35.0,17.2$ & \\
\hline $\mathbf{7 g}$ & & &
\end{tabular}

tions at $2 \theta=20.5-21.4^{\circ}$ were recognized. The nitro group-rich polymers tend to have longer $d$-spacing values than those of the methoxy group-rich polymers, whose values decrease with increasing the methoxyazobenzene content in the copolymers. The polymers 7a-g having longer aliphatic spacers in the side chain possess higher $d$-spacing values than the corresponding ones $5 \mathbf{a}-\mathbf{g}$ and $\mathbf{6 a}-\mathbf{g}$ with shorter chains. These data suggest that all the combined-type homo- and copolyesters $5 \mathbf{a}-\mathbf{g}, \mathbf{6 a}-\mathbf{g}$ and $7 \mathbf{a}-\mathbf{g}$ in this work form smectic phase (smectic B, C or E) in spite of the presence of different mesogens both in the main chain and in the side chain.

The homopolymers $5 \mathbf{a}, \mathbf{6 a}$ and $7 \mathbf{a}$ with electronwithdrawing (nitro) group have a tendency to form highly ordered smectic phase (smectic E), probably due to stronger intermolecular interaction between the side-chain nitroazobenzene, and the 1,3-phenylene and the biphenyl rings in the main chain and the homopolymers $5 \mathrm{~g}, \mathbf{6 g}$ and $\mathbf{7 g}$ with electron-donating (methoxy) group form smectic C or B phase, because of weaker intermolecular interaction between the sidechain methoxyazobenzene unit and the aromaric rings in the main chain. The mesophases change in the order of smectic E, smectic B and smectic C with increasing the side-chain aliphatic chain length ( $m=6,8$ and 10) and the methoxyazobenzene content, which means that intermolecular interaction by nitroazobenzene unit becomes weak with the increment of the methoxyazobenzene unit.

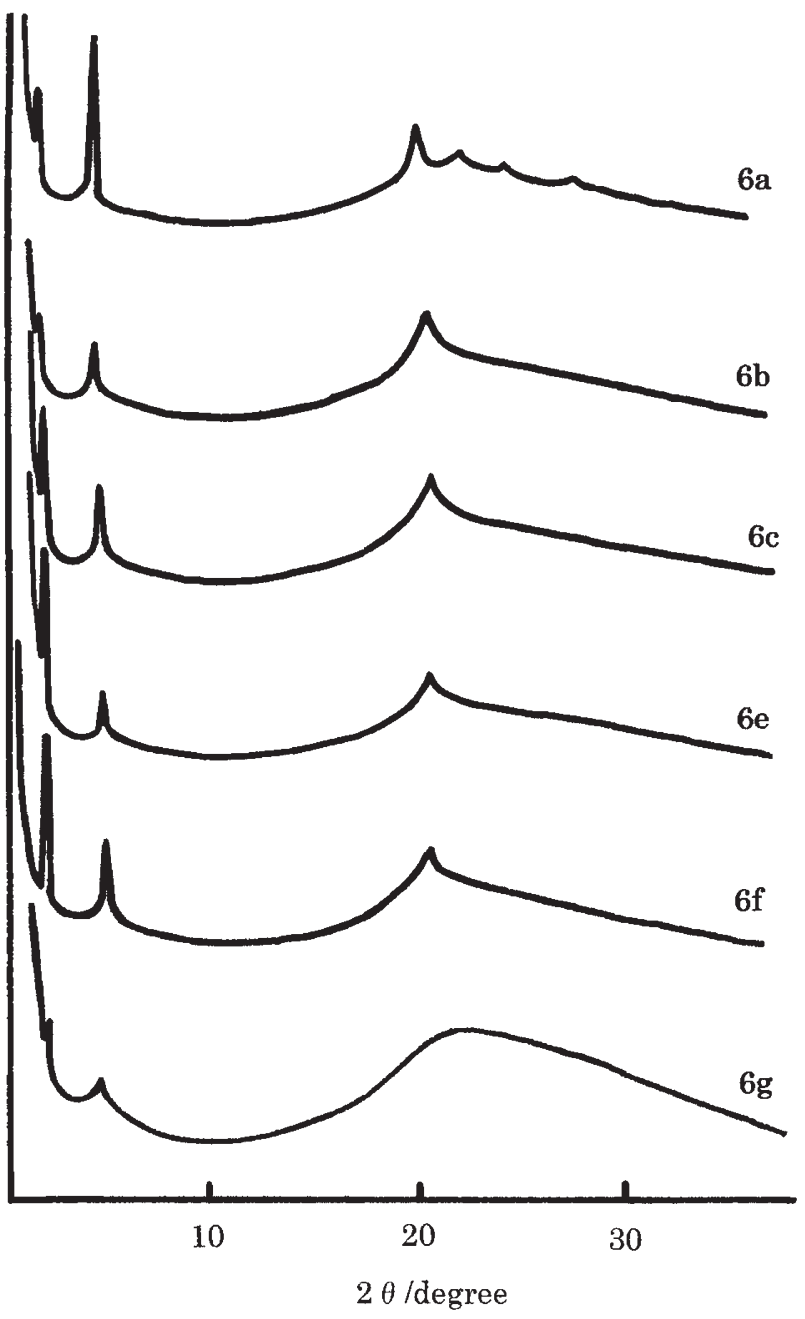

Figure 5. Powder X-Ray diffraction patterns of polyesters 6a-g.

The copolymers $\mathbf{5 b}-\mathbf{f}, \mathbf{6 b}-\mathbf{f}$ and $\mathbf{7 b}-\mathbf{f}$ display less ordered (smectic B) phase than the homopolymers 5a, 6a and 7a (smectic E), but more ordered (smectic B) phase than the homopolymers $\mathbf{5 g}$ and $\mathbf{6 g}$ (smectic C). This means that the ordering of polyester chains gradually increases with the increment of the nitroazobenzene content and the homopolymers $\mathbf{5 a}$, 6a and $7 \mathbf{a}$ have the highest ordered state in these polyesters $5 \mathbf{a}-\mathbf{g}, \mathbf{6 a}-\mathbf{g}$ and $7 \mathbf{a}-\mathbf{g}$.

These data suggest that the specific interaction such as electron donor-acceptor interaction between electron-withdrawing (nitro) and electron-donating (methoxy) groups has no role in the formation and the stabilization of smectic LC phases in these copolymers 5b-f, $\mathbf{6 b}-\mathbf{f}$ and $\mathbf{7 b}-\mathbf{f}$ contrary to our expectation. It is probably due to that steric effect of the main-chain 1,3-phenylene unit or aggregation effect of the aromatic rings in the main chain and the side-chain azobenzenes hinders overlapping of the electron-withdrawing and the electron-donating azobenzene units, and suppresses the specific electron donor-acceptor interaction because these copolyesters $\mathbf{5 b}-\mathbf{f}, \mathbf{6 b}-\mathbf{f}$ 
and $\mathbf{7 b}-\mathbf{f}$ have the rigid-rod biphenyl unit in the main chain, unlikely the copolymalonates composed of the flexible aliphatic chains in the main chain and the side-chain azobenzene units. ${ }^{22}$ The introduction of 1,3-phenylene ring as linking site of the main chain and the side chain in the combined-type copolymers is assumed to lead to no stabilization of thermotropic LC phases. It is necessary for obtaining combinedtype polymers having wider temperature ranges of thermotropic smectic LC phases to investigate the polymer structure-LC property relationship in more detail.

\section{Optical Properties}

Absorption and fluorescent properties of the polymers $5 \mathbf{a}-\mathbf{g}, \mathbf{6} \mathbf{a}-\mathbf{g}$ and $7 \mathbf{a}-\mathbf{g}$ in chloroform solutions and in films were examined. In the UV-vis spectra of polymers in the solutions, absorption peak maxima $\left(\lambda_{\max }\right)$ based on $\pi-\pi^{*}$ transition of the azobenzene units were observed in the range of 358.5 and $379.5 \mathrm{~nm}$, where the homopolymers $5 \mathbf{a}, 6 \mathbf{a}$ and $7 \mathbf{a}$ with the nitroazobenzene unit show the $\lambda_{\max }$ at $379.5 \mathrm{~nm}$ and those $\mathbf{5 g}, \mathbf{6 g}$ and $\mathbf{7 g}$ with the methoxyazobenzene moiety at $358.5-361.5 \mathrm{~nm}$. The $\lambda_{\max }$ changed systematically and were blue-shifted with increasing the methoxyazobenzene content. Broad and weak absorptions due to $n-\pi^{*}$ transition of the azobenzene units were also recognized at around 450$460 \mathrm{~nm}$. The solid states UV-vis spectra of polymer films cast from the chloroform solutions showed $\lambda_{\max }$ at $359.5-366.0 \mathrm{~nm}$. The homopolymers 5a, 6a and $7 \mathbf{a}$ having the nitroazobenzene unit displayed the $\lambda_{\max }$ at longer wave lengths than the methoxyazobenzene-containing homopolymers $5 \mathrm{~g}, \mathbf{6 g}$ and $7 \mathrm{~g}$ and the $\lambda_{\max }$ of copolymers $\mathbf{5 b}-\mathbf{f}, \mathbf{6} \mathbf{b}-\mathbf{f}$ and $7 \mathbf{b}-\mathbf{f}$ have a tendency to be blue-shifted with increase of the methoxyazobenzene content as well as those in the solutions. In the nitroazobenzene-rich copolymers, the $\lambda_{\max }$ were observed at lower wave lengths than those in the chloroform solutions, probably due to the intermolecular interaction between polymer chains with the nitroazobenzene unit in the films, but the methoxyazobenzene-rich copolymers show the $\lambda_{\max }$ at similar wave lengths to those of the homopolymers $5 \mathrm{~g}, \mathbf{6 g}$ and $7 \mathbf{g}$ composed with the methoxyazobenzene unit. The UV-vis spectral data for polymers 5a-g, 6a$\mathbf{g}$ and $\mathbf{7 a}-\mathbf{g}$ in the solutions and in the films are tabulated in Table VI. The UV-vis spectra for polymesters 6a-g in the chloroform solutions are illustrated in Figure 6.

The PL spectra of homo- and copolyesters $\mathbf{5 a}-\mathbf{g}$, 6a- $\mathbf{g}$ and $7 \mathbf{a}-\mathbf{g}$ were tried to be measured in the chloroform solutions and in the films. Unfortunately all the polymers in this work showed no fluorescence both in the solutions and in the films as well as our
Table VI. UV-vis spectral data for polyesters

\begin{tabular}{ccc}
\multicolumn{3}{c}{$\mathbf{5 a - g}, \mathbf{6 a}-\mathbf{g}$ and $\mathbf{7 a}-\mathbf{g}$} \\
\hline Polym. & $\begin{array}{c}\text { Solution in } \mathrm{CHCl}_{3} \\
\lambda_{\max } / \mathrm{nm}\end{array}$ & $\begin{array}{c}\text { Film } \\
\text { max }\end{array}$ \\
\hline $\mathbf{5 a}$ & 379.5 & 362.5 \\
$\mathbf{5 b}$ & 376.0 & 362.5 \\
$\mathbf{5 c}$ & 373.5 & 359.5 \\
$\mathbf{5 d}$ & 369.0 & 360.0 \\
$\mathbf{5 e}$ & 363.0 & 361.0 \\
$\mathbf{5 f}$ & 360.0 & 360.5 \\
$\mathbf{5 g}$ & 361.0 & 361.0 \\
$\mathbf{6 a}$ & 379.5 & 366.0 \\
$\mathbf{6 b}$ & 376.5 & 363.0 \\
$\mathbf{6 c}$ & 373.0 & 362.5 \\
$\mathbf{6 d}$ & 370.5 & 362.5 \\
$\mathbf{6 e}$ & 364.0 & 361.0 \\
$\mathbf{6 f}$ & 360.0 & 361.0 \\
$\mathbf{6 g}$ & 358.5 & 360.5 \\
$\mathbf{7 a}$ & 379.5 & 365.5 \\
$\mathbf{7 b}$ & 376.5 & 364.0 \\
$\mathbf{7 c}$ & 373.0 & 363.0 \\
$\mathbf{7 d}$ & 370.0 & 362.0 \\
$\mathbf{7 e}$ & 365.0 & 362.0 \\
$\mathbf{7 f}$ & 360.5 & 361.0 \\
$\mathbf{7 g}$ & 358.5 & 361.0 \\
\hline
\end{tabular}

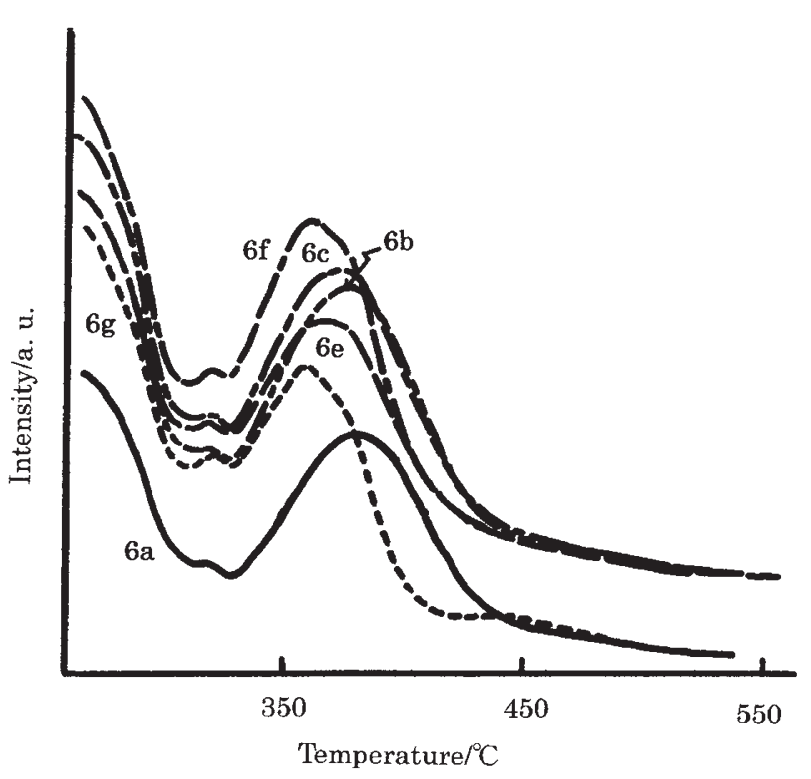

Figure 6. UV-vis spectra of polyesters $\mathbf{6 a}-\mathbf{g}$ in chloroform solutions.

previously-reported homopolymers $5 \mathbf{a}, \mathbf{5 g}, \mathbf{7 a}$ and $\mathbf{7 g},{ }^{20}$ although the PPV having the side-chain methoxyazobenzene unit has been reported to emit fluorescence by Wang et al. ${ }^{19}$ The reason why the polyesters in this work do not fluoresce might be considered that nonradiative decays from the photoexcited polyester chain to the azo and/or nitro groups, especially intra- and intermolecular quenching, occur and result in no fluorescence. Because the PPV composed of 
the methoxyazobenzene unit has the longer conjugated chains in the backbones and their transition energies are lower than those in the azobenzenes, the energy transfer process involving the luminescence proceeds probably more effectively than the nonradiative decays to the azobenzenes, followed by fluorescence without quenching in the PPV.

\section{CONCLUSIONS}

(1) The homopolyesters having electron-withdrawing nitro group displayed highly ordered smectic E phase and the ones with electron-donating methoxy group formed smectic B or C phase. All the copolyesters formed less ordered phase than the homopolyesters having the nitro group, but more ordered phase than those with the methoxy group. The LC temperature ranges of copolymers decreased linearly with increasing the methoxyazobenzene content independent of the copolymer composition owing to steric or aggregation effect of the main-chain aromatic rings.

(2) All the polyesters exhibited the absorptions on the basis of $\pi-\pi^{*}$ transition in the solution and the solid-state UV-vis spectra, and the $\lambda_{\max } \mathrm{s}$ of copolymers were systematically blue-shifted with increase of the methoxyazobenzene content. Unfortunately they exhibited no fluorescence, probably due to nonradiative decays, especially intra- and intermolecular quenching.

Acknowledgment. The authors are grateful to Ms. Michiko Egawa for her help in obtaining the elemental analysis data.

\section{REFERENCES}

1. A. Greiner and H.-W. Schmidt, in "Handbook of Liquid Crystals," D. Demus, J. Goodby, G. W. Gray, H.-W. Spiess, and V. Vill, Ed., Wiley-VCH, Weinheim, 1998, Vol 3, p 3.

2. B. W. Endres, M. Ebert, J. H. Wendorff, B. Rech, and H., Ringsdorf, Liq. Cryst., 7, 217 (1990).

3. R. Zentel, in "Handbook of Liquid Crystals," D. Demus, J. Goodby, G. W. Gray, H.-W. Spiess, and V. Vill, Ed., Wiley-VCH, Weinheim, 1998, Vol 3, p 52.

4. C. Pugh and A. L. Kiste, in "Handbook of Liquid Crystals," D. Demus, J. Goodby, G. W. Gray, H.-W. Spiess, and
V. Vill, Ed., Wiley-VCH, Weinheim, 1998, Vol 3, p 121.

5. C. B. McArdle, "Side Chain Liquid Crystal Polymers," Chapmann and Hall Inc., New York, N.Y., 1998.

6. V. Cimrova, D. Neher, S. Kostromine, and T. Bieringer, Macromolecules, 32, 8496 (1999).

7. M. Sato, K. Hayakawa, K. Nakagawa, K. Mukaida, and H. Fujiwara, Macromol. Rapid Commun., 15, 21 (1994).

8. M. Sato, K. Nakagawa, K. Hayakawa, K. Mukaida, H. Fujiwara, and Y. Tada, Macromol. Chem. Phys., 196, 2955 (1995).

9. K. Nakagawa, M. Sato, K. Mukaida, and H. Fujiwara, Opt. Rev., 2, 460 (1995).

10. M. Sato, K. Nakagawa, Y. Tada, and S. Ujiie, Macromol. Rapid Commun., 18, 273 (1997).

11. R. Stockermans and P. Rochon, Appl. Opt., 38, 3714 (1999).

12. D. Eaton, Science, 253, 281 (1991).

13. M. Eich and J. H. Wendorff, J. Opt. Soc. Am. B, 7, 1428 (1990).

14. E. Mohajerani, E. Whale, and G. R. Mitchell, Opt. Commun., 92, 403 (1992).

15. S. Xie, A. Natansohn, and P. Rochon, Chem. Mater., 5, 403 (1993).

16. F. Lagugne-Labarthet, T. Buffeteau, and C. Sourisseau, J. Appl. Phys., 90, 3149 (2001).

17. G. S. Kumar, "Azo Functional Polymers," Technomic Publishing Co., Inc., Lancaster, PA, 1992.

18. G. Wang, M. Li, M. Yu, C. Guo, X. Chen, G. Li, and E. Zhou, Liq. Cryst., 27, 867 (2000).

19. G. Wang, M. Li, X. Chen, F. Wu, W. Tian, and J. Shen, Macromol. Rapid Commun., 20, 591 (1999).

20. M. Sato, M. Mizoi, and Y. Uemoto, Macromol. Chem. Phys., 202, 3634 (2001).

21. S. Diele, M. Naumann, F. Kuschel, B. Reck, and H. Ringsdorf, Liq. Cryst., 7, 721 (1990).

22. T. Kodaira, M. Endo, and M. Kurachi, Macromol. Chem. Phys., 199, 2329 (1998).

23. C. T. Imrie and B. J. A. Paterson, Macromolecules, 27, 6673 (1994).

24. Y. Kosaka and T. Uryu, Macromolecules, 28, 870 (1995).

25. M. Sato, T. Yoshinaga, and N. Koide, Polym. J., 32, 753 (2000).

26. H. Qiu, M. Li, X. Chen, F. Jing, and E. Zhou, Liq. Cryst., 25, 419 (1998).

27. C. T. Imrie, F. E. Karasz, and G. S. Attard, Liq. Cryst., 9, 47 (1991).

28. C. T. Imrie, F. E. Karasz, and G. S. Attard, Macromolecules, 25, 1278 (1992).

29. Y. Takenaka, K. Osakada, M. Nakano, and T. Ikeda, Macromolecules, 36, 1414 (2003). 